\title{
REVIEW
}

\section{The leptin-dependent and -independent melanocortin signaling system: regulation of feeding and energy expenditure}

\author{
Hiroyuki Shimizu, Kinji Inoue $\mathbf{1}$ and Masatomo Mori \\ Department of Medicine and Molecular Science, Gunma University Graduate School of Medicine, Maebashi 371-8511, Japan \\ ${ }^{1}$ Department of Regulation Biology, Saitama University, Saitama 378-8570, Japan \\ (Requests for offprints should be addressed to M Mori; Email: mmori@med.gunma-u.ac.jp)
}

\begin{abstract}
The brain hypothalamus coordinates extra-hypothalamic regions to maintain energy homeostasis through the regulation of food intake and energy expenditure. A number of anorexigenic and orexigenic molecules in the hypothalamic nuclei participate in the control of energy homeostasis. Leptin and pro-opiomelanocortin (POMC)derived $\alpha$-melanocyte-stimulating hormone are key anorectic molecules, and the leptin receptor and POMC gene are both
\end{abstract}

expressed in the hypothalamic arcuate nucleus. Although it has been considered that melanocortin signaling is localized downstream to leptin signaling, data have accumulated to support the concept of a leptin-independent melanocortin signaling system. We focus on and review the melanocortin signaling system that functions dependently or independently of leptin signaling in the regulation of energy homeostasis.

Journal of Endocrinology (2007) 193, 1-9

\section{Introduction}

Obesity forms a fundamental basis of the metabolic syndrome that involves hyperglycemia, hypertension and hyperlipidemia (Wajchenberg 2000, Weiss et al. 2004, Eckel et al. 2005) and is strongly associated with a high incidence of arteriosclerosis and cardiovascular disease (Kenchaiah et al. 2002, Ferreira et al. 2004, Eckel et al. 2005, Saely et al. 2005, Yusuf et al. 2005, Sundstrom et al. 2006). In addition, obesity causes and exacerbates many health problems including non-alcoholic steatohepatitis, sleep apnea, osteoarthritis, cerebrovascular disease, gastroesophageal reflux, gallstones and certain types of cancers (Marceau et al. 1999, Chow et al. 2000, Tilg \& Diehl 2000, Stein \& Colditz 2004, Angelico et al. 2005, Jacobson et al. 2006). Currently, the incidence of obesity is increasing worldwide. In particular, the rate of obesity involving a body mass index over 30 has been estimated to exceed $30 \%$ of the population in the USA (Ogden et al. 2006). The same problem with respect to obesity has occurred in other countries including Europe and Asia (News feature 2004, Gu et al. 2005, Haslam \& James 2005, Kawamoto et al. 2005). Analysis of human subjects has shown that both increased adiposity and reduced physical activity are significant and independent predictors of death (Hu et al. 2004, Adams et al. 2006, Jee et al. 2006, Sundstrom et al. 2006).

Increased feeding and decreased energy expenditure lead to obesity (Spiegelman \& Flier 2001) and both are regulated essentially by the hypothalamus. The hypothalamus is a known center for the regulation of fundamental behaviors including appetite, thirst, temperature, sexual activity and locomotion. There are complex but integrated interconnections among the hypothalamic nuclei that coordinate the maintenance of energy homeostasis through regulating food intake and energy expenditure (Schwartz et al. 2000, Flier 2004, Schwartz \& Porte 2005, Stanley et al. 2005). The individual nuclei of the hypothalamus contain characteristic molecules that exert either an anorexigenic or orexigenic function depending on their hypothalamic locations (Woods et al. 1998, Kalra et al. 1999, Shimizu \& Mori 2005). In particular leptin and pro-opiomelanocortin (POMC)derived $\alpha$-melanocyte-stimulating hormone (MSH) show strong anorexigenic activities and exert their effects as integrated key molecules in regulating energy homeostasis at the hypothalamic and extra-hypothalamic level (Friedman \& Halaas 1998, Schwartz et al. 2000, Stanley et al. 2005).

Although leptin has different effects on the gene expression of hypothalamic anorexigenic molecules such as cocaine- and amphetamine-regulated transcript (CART) and $\mathrm{POMC}$, and on the gene expression of orexigenic molecules such as neuropeptide Y (NPY) and agouti-related peptide (AgRP) (Schwartz et al. 1996, Morrison et al. 2005, Kitamura et al. 2006), in the present review, we discuss what is currently known about the melanocortin signaling system that functions dependently and independently of 
leptin signaling in the regulation of food intake and energy expenditure.

\section{Brain melanocortin signaling involved in regulating energy homeostasis}

POMC is expressed in the skin, the pituitary gland and the hypothalamus (Yeo et al. 2000), and undergoes tissue-specific posttranslational processing (Pritchard et al. 2002). In the anterior pituitary, POMC is processed predominantly to adrenocorticotropic hormone (ACTH) and $\beta$-lipotropin $(\mathrm{LPH})$. In the hypothalamus and the neurointermediate lobe of the pituitary, POMC is more extensively processed (Fig. 1). ACTH is further processed to produce $\alpha-\mathrm{MSH}, \mathrm{N}$-terminal fragment of POMC is further processed to $\gamma-\mathrm{MSH}$, and $\beta-\mathrm{LPH}$ is further processed to $\beta-\mathrm{MSH}$ and $\beta$-endorphin (Pritchard et al. 2002, Coll et al. 2004). There are species differences in the products of POMC processing; for instance, in humans, $\gamma-\mathrm{LPH}$ is cleaved to produce $\beta-\mathrm{MSH}$, which is not found in rats (Pritchard et al. 2002, Coll et al. 2004).

The biological effects of POMC-derived fragments are mediated by interaction with specific $G$ protein-coupled seven-transmembrane receptors. Five different receptors have been well characterized. Among these, melanocortin-3 receptor (MC3R) and melanocortin-4 receptor (MC4R) are present in the brain and exert their function in the regulation of energy homeostasis. Whereas $\alpha-\mathrm{MSH}$ binds both MC3R and
MC4R (MC3/4R), $\gamma$-MSH binds MC3R (Millington et al. 2001, Pritchard et al. 2002). Mice deficient in MC3R or MC4R become obese (Huszar et al. 1997, Butler et al. 2000), and mice lacking both MC3R and MC4R have a greater level of obesity compared with mice lacking MC4R only (Chen et al. 2000). Mice deficient in MC3R or MC4R show different characteristics with respect to feeding behavior; MC4Rdeficient mice exhibit increased food intake and defects in metabolism, whereas MC3R-deficient mice show increased fat mass without a concomitant increase in food intake even on a high fat diet (Butler et al. 2000, Chen et al. 2000, Sutton et al. 2006). Different responses to peripheral signaling also occur in melanocortin receptor subtypes; MC4R-knockdown mice are resistant to cachexia, but MC3R-deficient mice are highly susceptible to cachexia (Marks et al. 2003). As administration of a specific agonist for MC3R causes a reduction of action potentials in POMC-containing neurons of the arcuate nucleus (Arc) (Cowley et al. 2001), it is reasonable to assume that peripheral administration of an agonist for MC3R would stimulate food intake (Marks et al. 2006). In line with these views, it is proposed that MC3R acts as an inhibitory autoreceptor on POMC neurons. Under MC4R-deficient conditions, the mice no longer respond to the anorectic action of melanotetan II (MT-II), which is a potent agonist not only for MC4R but also for MC3R. Together, these observations lead to the concept that suppression of food intake is primarily due to activation of MC4R (Marsh et al. 1999).

POMC processing pathway in the hypothalamus

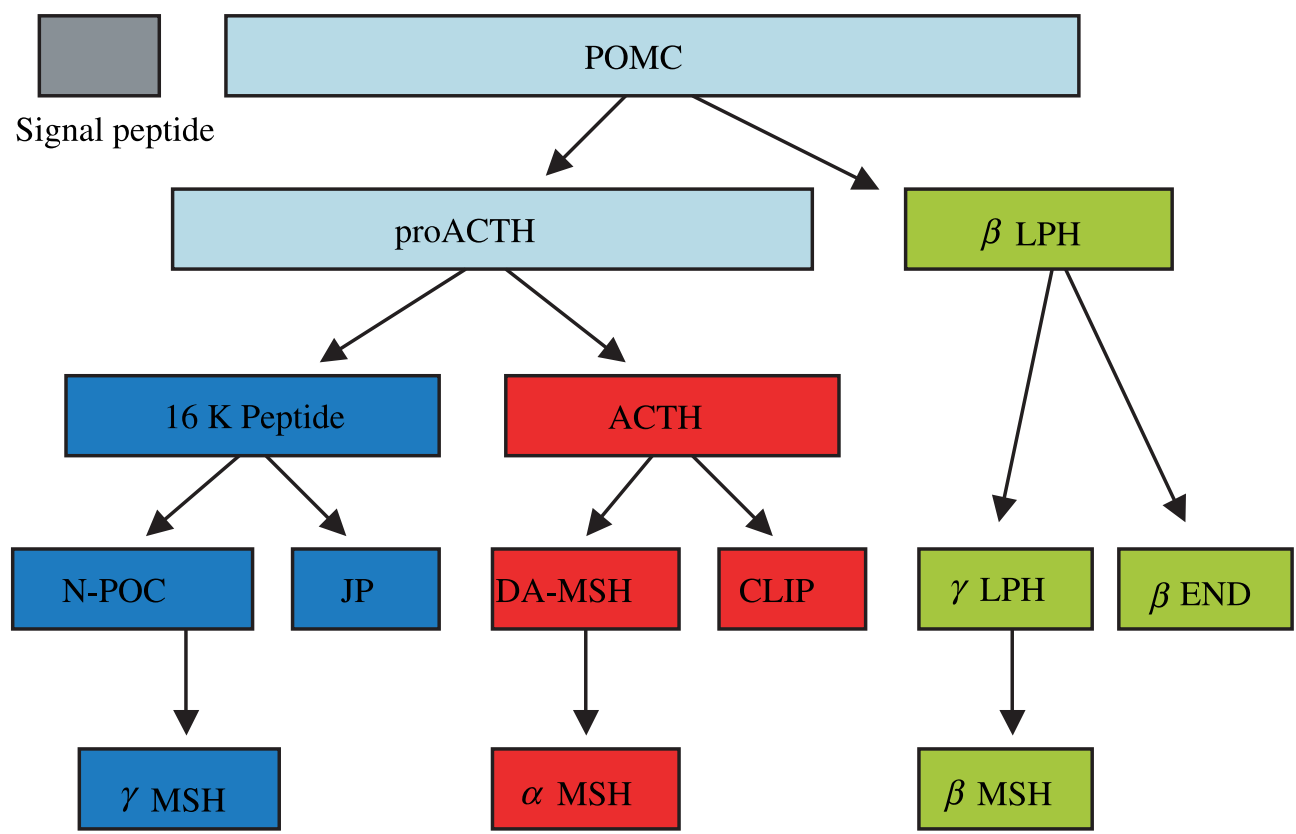

Figure 1 Processing pathway of pro-opiomelanocortin (POMC) in the hypothalamus. N-POC, N-terminal fragment of POMC; JP, junction peptide; DA-MSH, deacetyl MSH; CLIP, corticotropin-like intermediate lobe peptide; LPH, lipotropin; END, endorphin. 
The endogenous molecules antagonizing melanocortin receptors in the brain are agouti and agouti-related peptide (AgRP). Agouti mice $\left(A^{\mathrm{y}} / a\right)$ are characterized by ectopic overexpression of agouti protein, which antagonizes skin MC1R and hypothalamic $\mathrm{MC} 3 / 4 \mathrm{R}$, resulting in altered skin pigmentation and increased food intake ( $\mathrm{Lu}$ et al. 1994). AgRP, a protein homologous to agouti, is localized in the hypothalamus (Ollmann et al. 1997) and causes increased food intake and body weight (Small et al. 2001); the selective ablation of AgRPexpressing neurons results in acute reduction in feeding (Gropp et al. 2005). However, it is not surprising to find that administration of $\alpha-\mathrm{MSH}$ and MT-II causes an apparent inhibitory action on feeding in agouti mice (Fan et al. 1997, Zheng et al. 2002, Martin et al. 2004), because AgRP/agouti also acts as an inverse agonist for a constitutively active MC4R (Haskell-Luevano \& Monck 2001, Nijenhuis et al. 2001, Pritchard \& White 2005).

There are specific localizations of POMC, MC3R and MC4R gene expression in the brain. Neurons expressing POMC in the brain are restricted to the Arc and the nucleus of the tract solitarius, and POMC gene expression in the Arc is positively regulated by several endogenous molecules including corticotropin-releasing hormone $(\mathrm{CRH})$, insulin, glucocorticoid and leptin (Schwartz et al. 1997, Wardlaw et al. 1998, Kim et al. 1999). The processed products of POMC affect the expression of the POMC gene differently depending on the area of injection; e.g. injection of $\alpha-\mathrm{MSH}$ intracerebroventricularly stimulates (Kim et al. 2005) while injection of $\alpha-\mathrm{MSH}$ into the paraventricular nucleus (PVN) inhibits expression of the POMC gene (Kim et al. 2002). In contrast to the restricted distribution of the POMC gene, MC3R and MC4R are widely present throughout the brain, and their distributions appear different. MC3R is exceptionally dense in the appetite controlrelated areas of the hypothalamic nuclei such as the Arc, ventromedial nucleus, and preoptic nucleus (Roselli-Rehfuss et al. 1993, Jegou et al. 2000). On the other hand, MC4R shows intense distribution in the hypothalamic nuclei (Fig. 2) including the PVN, the dorsomedial hypothalamus (DMH) and the lateral hypothalamic area (LHA) (Mountjoy et al. 1994, Kishi et al. 2003, Liu et al. 2003). The important roles that $\mathrm{POMC}$ and MC4R play in the regulation of energy balance are evident from the presence of severe obesity in gene-knockout mice (Huszar et al. 1997, Yaswen et al. 1999) and in human subjects with mutations (Krude et al. 1998, Farooqi et al. 2003). Obesity in the knockout mice results from the combined influences of increased food intake and decreased energy expenditure (Huszar et al. 1997, Yaswen et al. 1999, Ste Marie et al. 2000, Balthasar et al. 2005). Individual functions mediated by MC4R occur in different brain regions, and integrated interconnections among the brain regions expressing MC4R have been identified in the regulation of energy homeostasis (Cone 2005). It is of interest to note that in MC4R-deficient mice receiving MC4R-overexpression in the PVN and amygdala, hyperphagia is completely reversed, whereas reduced energy expenditure is unaffected, suggesting that MC4R in the PVN specifically regulates food intake, while MC4R

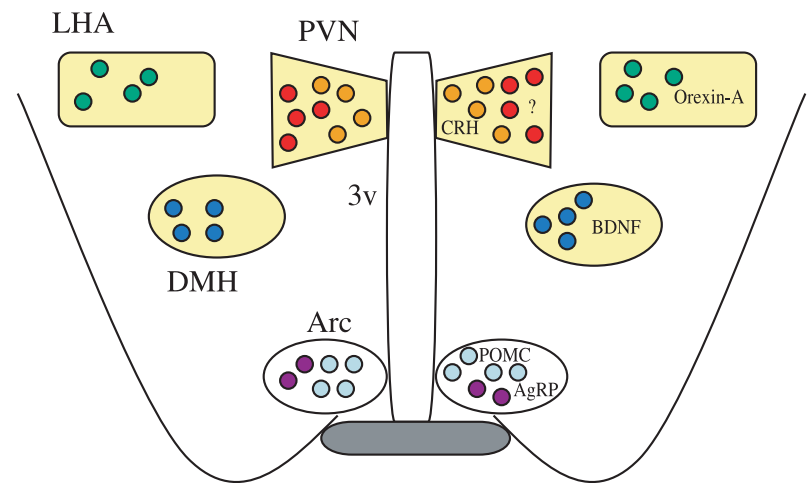

Figure 2 Hypothalamic expression of melanocortin-4 receptor (MC4R) and appetite-control molecules associated with MC4R signaling. MC4R is exceptionally dense (yellow-coloured boxes) in the paraventricular nucleus (PVN), dorsomedial hypothalamus $(\mathrm{DMH})$ and lateral hypothalamic area (LHA). CRH, corticotropinreleasing hormone; BDNF, brain-derived neurotropic factor; POMC, pro-opiomelanocortin; AgRP, agouti-related peptide; Arc, arcuate nucleus; $3 \mathrm{v}$, third ventricle.

in other regions mainly controls energy expenditure (Balthasar et al. 2005).

\section{Leptin-dependent melanocortin signaling}

Leptin originating in peripheral adipose tissue reaches the hypothalamus and binds the active form of the leptin receptor $(\mathrm{Ob}-\mathrm{Rb})$ that is localized in the Arc (Friedman \& Halaas 1998, Schwartz et al. 2000), where the POMC-expressing neurons co-localize with Ob-Rb (Cheung et al. 1997, Munzberg et al. 2003). Certain physiological conditions that cause changes in the blood level of leptin influence the activity of POMC. For instance, POMC gene expression in the Arc is decreased in leptin-deficient $o b / o b$ mice and in $d b / d b$ mice with an Ob-Rb mutation (Mizuno et al. 1998). Conversely, administration of leptin causes a significant stimulation of POMC gene expression in the Arc (Schwartz et al. 1996, Morrison et al. 2005, Kitamura et al. 2006), and also increases the frequency of action potentials in Arc POMC neurons (Cowley et al. 2001, van den Top et al. 2004). These data are interpreted as supporting the concept that the melanocortin signaling system basically lies downstream of leptin signaling in the Arc. This concept is compatible with the observations showing the effectiveness of melanocortin signaling in the absence of leptin signaling. Over-expression of POMC ameliorates metabolic abnormalities under the leptin-deficient condition of $o b / o b$ mice (Mizuno et al. 2003), and expression of the POMC gene in the hypothalamic Arc causes reduction of food intake and weight loss in Zucker rats with a leptin receptor mutation ( $\mathrm{Li}$ et al. 2003).

The hypothalamus also plays a pivotal role in organizing glucose output from the liver (Obici et al. 2002), in which glucose metabolism is mediated by leptin through activation on the central nervous system (Kamohara et al. 1997). In fact, 
hepatic expression of gluconeogenic enzymes such as glucose-6-phosphate and phosphoenolpyruvate carboxykinase is stimulated by leptin via activation of melanocortin signaling (Gutierrez-Juarez et al. 2004), indicating the downstream localization of melanocortin signaling in relation to leptin signaling.

What molecule(s) in the PVN is(are) involved in the leptindependent melanocortin signaling upon the regulation of energy balance (Fig. 2)? Neurons expressing $\mathrm{CRH}$ are localized in the PVN and CRH is one of the hypothalamic anorexigenic molecules (Shimizu \& Mori 2005). Urocortin is a CRH-related endogenous peptide that induces satiety at the site of the PVN (Currie et al. 2001, Kotz et al. 2002), but urocortin-deficient mice have been observed to show normal basal feeding behavior (Vetter et al. 2002). The CRH-induced satiety function is closely connected with leptin signaling. Not only leptin but also MT-II, an agonist for melanocortin receptors, increase CRH mRNA expression in the PVN (Schwartz et al. 1996, Lu et al. 2003), and the anorexigenic function induced by both leptin and MT-II is hampered by a CRH receptor antagonist (Uehara et al. 1998, Lu et al. 2003). These findings suggest that $\mathrm{CRH}$ in the PVN is a downstream mediator of both leptin and melanocortin signaling. However, the anorectic action induced by $\mathrm{CRH}$ is not disturbed in MC4R-deficient mice (Marsh et al. 1999) and is not blocked by HSO14, an antagonist for MC4R (Vergoni et al. 1999). These observations are in agreement with the finding that central administration of AgRP does not block CRH-induced feeding suppression (Edwards et al. 2000). Leptin and CRH exert a central action on energy expenditure by activating sympathetic nerve activity (Arase et al. 1988, Luo et al. 2005, Montanaro et al. 2005).

These findings imply that the regulation of energy homeostasis requires the sequential and central relay of leptin and its receptor in the Arc to stimulate melanocortin signaling that is connected with neurons expressing $\mathrm{CRH}$ in the PVN (Fig. 3).

\section{Leptin-independent melanocortin signaling}

All POMC neurons do not express leptin receptors in the hypothalamus (Cheung et al. 1997, Munzberg et al. 2003), suggesting the existence of a leptin-unrelated melanocortin signaling system.

With respect to energy homeostasis, melanocortin receptors may respond differently to leptin signaling. While leptin administration reduces food intake in MC4R-deficient mice, MC3R-deficient mice do not respond to leptininduced anorexia, indicating that the ability of leptin to

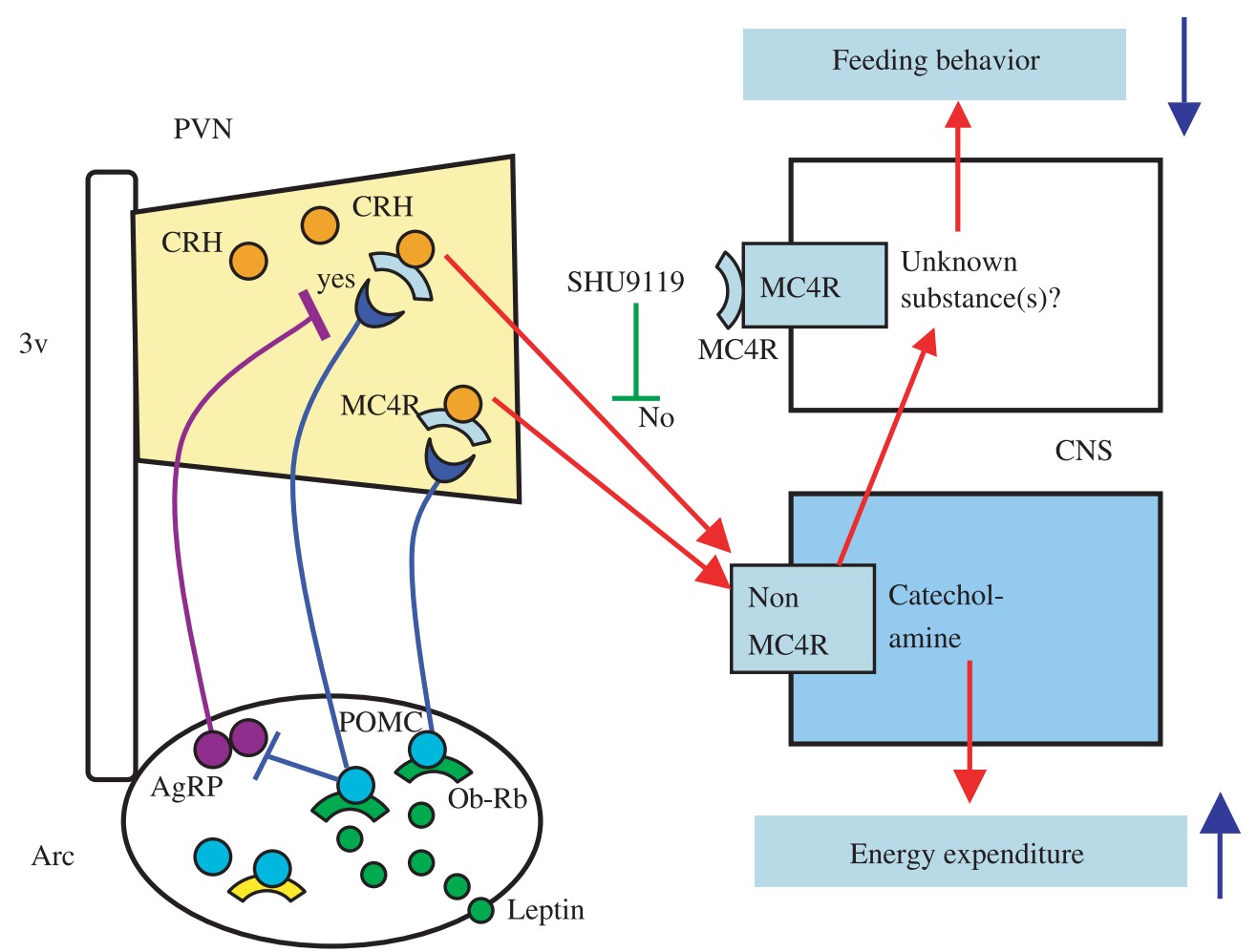

Figure 3 The possible pathway associated with leptin-dependent melanocortin signaling in the regulation of energy expenditure. The $\mathrm{CRH}$-induced energy expenditure is not inhibited by SHU9119. Ob-Rb, leptin receptor; SHU9119, an MC3/4R antagonist; CNS, central nervous system. Other abbreviations are the same as shown in Fig. 2. 
reduce food consumption depends on MC3R, but not on MC4R (Zhang et al. 2005). Previously, it had been shown that neither peripheral nor central administration of leptin induced body weight loss in obese mice deficient in MC4R or in obese agouti mice (Halaas et al. 1997, Marsh et al. 1999). However, these observations seem likely to be the result of leptin resistance found in non-specific obesity (Heymsfield et al. 1999, Ren 2004, Munzberg \& Myers 2005), because non-obese MC4R-deficient mice and agouti mice respond to leptin-induced anorexia (Marsh et al. 1999, Martin et al. 2004). These data are compatible, at least in part, with analysis of double-mutant agouti and $o b / o b$ mice that show accelerated obesity and restoration of leptin sensitivity (Boston et al. 1997), indicating leptin-independent roles for melanocortin signaling. In fact, under conditions of leptin resistance such as diet-induced obesity, peripheral administration of MT-II decreases food intake (Pierroz et al. 2002, Bluher et al. 2004) possibly via activation of MC4R (Marsh et al. 1999). These data provide evidence that MC4R-mediated appetite regulation is essentially independent of leptin signaling.

Another example that exhibits leptin-independent melanocortin signaling is the different sympathetic activation by leptin and $\alpha-\mathrm{MSH}$ in reducing energy expenditure. $\alpha-\mathrm{MSH}$ administration induces a sustained activation of resting energy expenditure (Hoggard et al. 2004) and, conversely, chronic administration of SHU9119, an antagonist for MC3/4R, leads to a decrease in body temperature and physical activity without changing CRH expression in the PVN (Adage et al. 2001). Leptin also induces sympathetic excitation in brown adipose tissue (Luo et al. 2005, Montanaro et al. 2005), but SHU9119 does not block this sympathetic excitation, whereas SHU9119 inhibits sympathetic nerve activity induced by MT-II (Haynes et al. 1999).

A third example of leptin-independent melanocortin signaling is derived from precise comparisons of different metabolic changes between MC4R-knockdown mice and leptin-deficient $o b / o b$ mice. These observations provide insights into the known relationship of the melanocortin system to leptin signaling (Huszar et al. 1997). Transition from a low-fat $(12 \cdot 8 \%)$ to a moderately high-fat $(25 \cdot 1 \%)$ diet markedly increases body weight gain in MC4R-deficient mice, but not in wild-type or ob/ob mice (Butler et al. 2001). In addition, it has become clear that MC4R signaling, but not leptin signaling, is indispensable for the induction of initial food intake, wheel running activity and oxygen consumption upon exposure to a high-fat diet, suggesting that MC4R takes part in an alternative pathway of the leptin-independent function (Butler et al. 2001).

A fourth example of leptin-independent melanocortin signaling may be the brain fat acid synthase (FAS)-related regulation of energy homeostasis. Alteration of fatty acids in the diet influences their concentration in the hypothalamus (Lam et al. 2005), and fatty acids play pivotal roles not only in the regulation of energy constancy, but also in the modulation of liver glucose metabolism. In the brain, administration of C75 (3carboxy-4-akyl-2-methylenebutyrolactone) and cerulenin inhibit FAS activity and leads to the accumulation of malonyl CoA, which induces an increase in long-chain fatty acids (LCFAs) and a subsequent decrease in carnitine palmitoyltransferase-1 (CPT1). Central and peripheral injection of C75 causes a reduction in food intake and body weight (Loftus et al. 2000), and inhibition of hypothalamic CPT1 decreases food intake and glucose production (Obici et al. 2003). Moreover, administration of LCFAs modulates hepatic gluconeogenesis to change the blood glucose level by affecting ATP-sensitive potassium channels in the hypothalamus (Lam et al. 2005, Pocai et al. 2005). Whereas FAS-linked regulation of energy balance is independent of leptin signaling (Loftus et al. 2000), acute administration of $\mathrm{C} 75$ prevents the fasting-induced downregulation of POMC expression and up-regulation of AgRP expression (Shimokawa et al. 2002, Aja et al. 2006). Although C75 has been claimed to be a nonspecific neuronal activator (Takahashi et al. 2004), brain FAS appears likely to require melanocortin signaling in the control of food intake and energy expenditure (Shimokawa et al. 2002, Aja et al. 2006).

The final example of leptin-independent melanocortin signaling is the hypothalamic role of nesfatin- 1 signaling in the regulation of food intake. MC4R is particularly dense in
Vehicle injection (antisense probe)

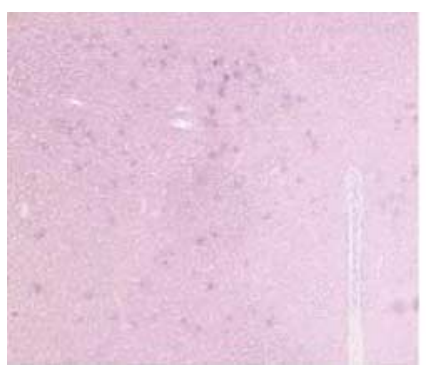

Figure 4 No effects of leptin on NUCB2/nesfatin gene expression in the PVN. Three hours after central administration of vehicle or $20 \mathrm{pmol}$ leptin, the rat brains were analyzed for gene expression using a digitoxigenin-labeled probe of NUCB2/nesfatin cRNA as described previously (Oh-I et al. 2006).

(sense probe)

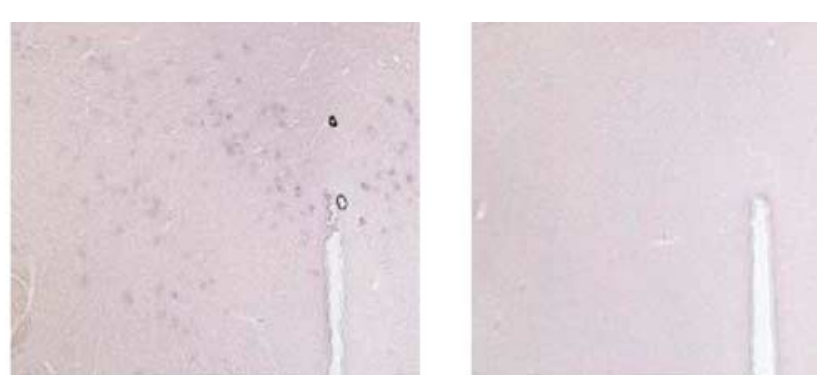

Leptin injection

(antisense probe)

. 


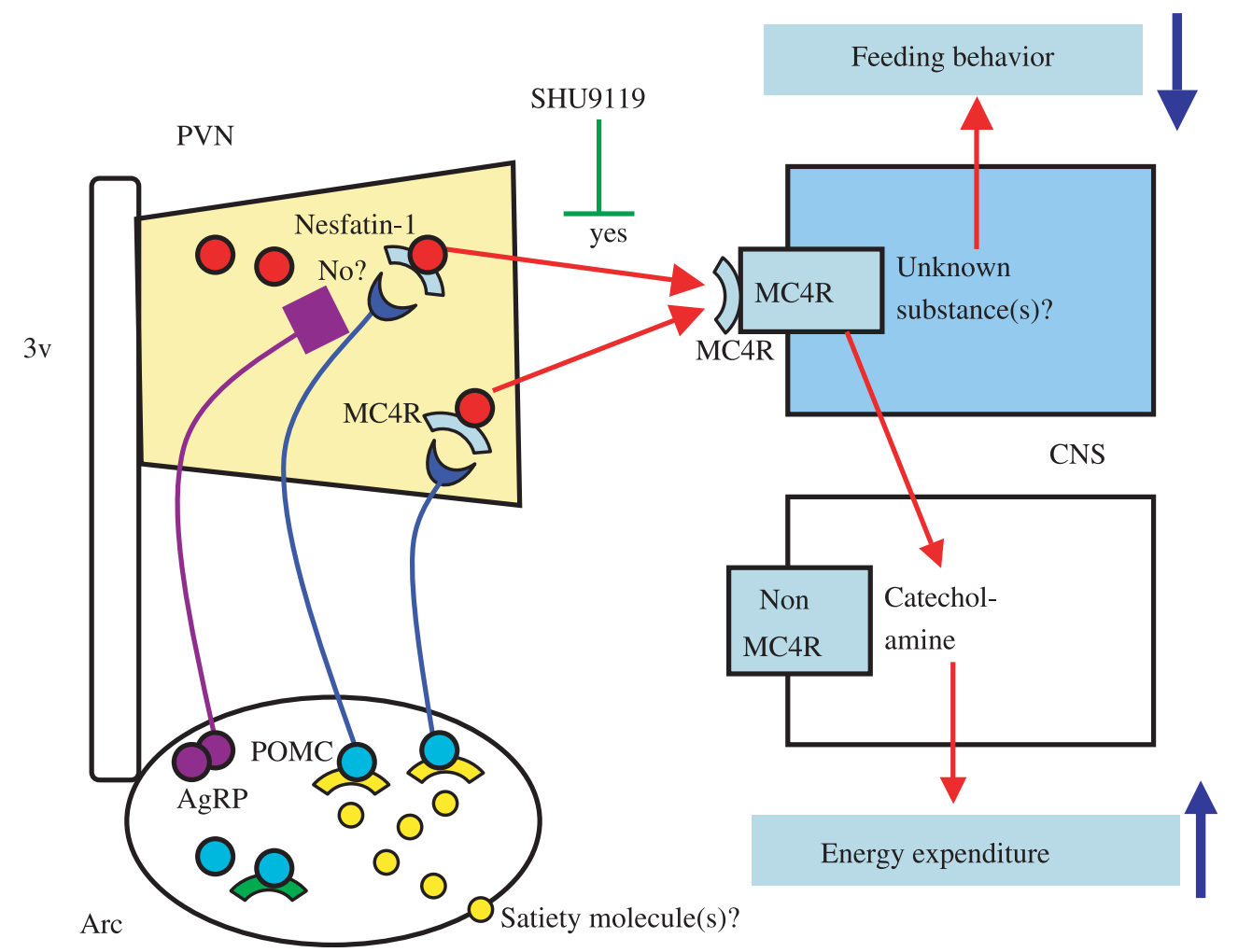

Figure 5 The proposed pathway associated with leptin-independent melanocortin signaling in the regulation of feeding behavior. Nesfatin-1-induced satiety signaling is abolished by SHU9119. Abbreviations are the same as shown in Figs 2 and 3.

the PVN, DMH and LHA in the hypothalamus (Fig. 2), all areas which participate in the regulation of appetite (Mountjoy et al. 1994, Kishi et al. 2003, Liu et al. 2003). The PVN and DMH are areas implicated in satiety, and the LHA is an area implicated in feeding. In the DMH, one anorexigenic molecule regulated by $\alpha-\mathrm{MSH}$-related MC4R signaling is brain-derived neurotropic factor (Xu et al. 2003), and an MC4R (AgRP)-mediated molecule in the LHA is orexin-A, a potent orexigenic molecule (Zheng et al. 2002). What molecule(s) in the PVN is(are) involved in the leptinindependent melanocortin signaling system? Recently, we identified nesfatin-1 as a novel satiety molecule that is processed from the precursor of NUCB2/nesfatin and distributed in the appetite-controlling hypothalamic nuclei including the Arc and the PVN (Oh-I et al. 2006). Under fasting conditions, nesfatin-1 concentrations are reduced in the PVN. At first, we examined the effect of leptin on gene expression of this molecule. Central administration of leptin does not change gene expression of NUCB2/nesfatin (Fig. 4). In addition, the satiety signal of this molecule is not disturbed in Zucker rats with a leptin receptor mutation, and prior administration of an anti-nesfatin- 1 antibody does not block leptin-induced anorexia, suggesting that leptin signaling does not participate primarily in nesfatin-1 signaling. In contrast, central administration of $\alpha-\mathrm{MSH}$ markedly stimulates NUCB2/nesfatin gene expression in the PVN (Oh-I et al. 2006). Prior administration of SHU9119 abolishes nesfatin-1-induced feeding suppression, but nesfatin-1 does not show any direct agonistic action on MC3R or MC4R. These observations are interpreted to support the concept that nesfatin-1 signaling involves the leptin-independent melanocortin signaling system in the hypothalamus.

Taken together, the findings imply a sequential and central mechanism in the regulation of energy homeostasis by which an unknown satiety molecule(s) reaches the Arc to stimulate melanocortin signaling-associated neurons expressing nesfatin-1 in the PVN (Fig. 5).

\section{Conclusion}

Hypothalamic signaling of leptin and melanocortin plays a key satiety role in regulating food intake and energy expenditure. Obese persons exhibit a consistent increase in blood levels of leptin, but feeding behaviors are not suppressed, implying a conditioned resistance to leptin (Heymsfield et al. 1999, Ren 2004, Munzberg \& Myers 2005). Therefore, it is important to evaluate melanocortin signaling that does not depend on leptin signaling in the hypothalamus. The present review raises the 
possibility that hypothalamic molecules contributing to leptinindependent melanocortin signaling are useful targets for the development of drug therapies to treat human obesity.

\section{Acknowledgements}

We thank Ms M Yoshiba and S Adachi for technical assistance. This work was supported in part by grants-in-aid from the Ministry of Health, Labor and Welfare of Japan (to M M). The authors declare that there is no conflict of interest that would prejudice the impartiality of this work.

\section{References}

Adage T, Scheurink AJ, de Boer SF, de Vries K, Konsman JP, Kuipers F, Adan RA, Baskin DG, Schwartz MW \& van Dijk G 2001 Hypothalamic, metabolic, and behavioral responses to pharmacological inhibition of CNS melanocortin signaling in rats. Journal of Neuroscience 21 3639-3645.

Adams KF, Schatzkin A, Harris TB, Kipnis V, Mouw T, Ballard-Barbash R, Hollenbeck A \& Leitzmann MF 2006 Overweight, obesity, and mortality in a large prospective cohort of persons 50 to 71 years olds. New England Journal of Medicine 355 763-778.

Aja S, Bi S, Knipp SB, McFadden JM, Ronnett GV, Kuhajda FP \& Moran TH 2006 Intracerebroventricular C75 decreases meal frequency and reduces $A g R P$ gene expression in rats. American Journal of Physiology. Regulatory, Integrative and Comparative Physiology 291 R148-R154.

Angelico F, Del Ben M, Conti R, Francioso S, Feole K, Fiorello S, Cavallo MG, Zalunardo B, Lirussi F, Alessandri C et al. 2005 Insulin resistance, the metabolic syndrome, and nonalcoholic fatty liver disease. Journal of Clinical Endocrinology and Metabolism 90 1578-1582.

Arase K, York DA, Shimizu H, Shargill N \& Bray GA 1988 Effects of corticotropin releasing factor on food intake and brown adipose tissue thermogenesis in rats. American Journal of Physiology. Endocrinology and Metabolism 255 E255-E259.

Balthasar N, Dalgaard LT, Lee CE, Yu J, Funahashi H, Williams T, Ferreira M, Tang V, McGovern RA, Kenny CD et al. 2005 Divergence of melanocortin pathways in the control of food intake and energy expenditure. Cell 123 493-505.

Bluher S, Ziotopoulou M, Bullen JW Jr, Moschos SJ, Ungsunan L, Kokkotou E, Maratos-Flier E \& Mantzoros CS 2004 Responsiveness to peripherally administered melanocortin in lean and obese mice. Diabetes $\mathbf{5 3} 82-90$.

Boston BA, Blavdon KM, Vamerin J \& Cone RD 1997 Independent and additive effects of central POMC and leptin pathways on murine obesity. Science 278 1641-1644.

Butler AA, Kesterson RA, Khong K, Cullen MJ, Pelleymounter MA, Dekoning J, Baetscher M \& Cone RD 2000 A unique metabolic syndrome causes obesity in the melanocortin-3 receptor-deficient mouse. Endocrinology 141 3518-3521.

Butler AA, Marks DL, Fan W, Kuhn CM, Bartolome M \& Cone RD 2001 Melanocortin-4 receptor is required for acute homeostatic response to increased dietary fat. Nature Neuroscience 4 605-611.

Chen AS, Marsh DJ, Trumbauer ME, Frazier EG, Guan XM, Yu H, Rosenblum CI, Vongs A, Feng Y, Cao L et al. 2000 Inactivation of the mouse melanocortin-3 receptor results in increased fat mass and reduced lean body mass. Nature Genetics 26 97-102.

Cheung CC, Cliton DK \& Steiner RA 1997 Proopiomelanocortin neurons are direct targets for leptin in the hypothalamus. Endocrinology 138 4489-4492.

Chow WH, Gridley G, Fraumeni JF Jr \& Jarvholm B 2000 Obesity, hypertension, and the risk of kidney cancer in men. New England Journal of Medicine 343 1305-1311.
Coll AP, Farooqi IS, Challis BG, Yeo GS \& O’Rahilly S 2004 Proopiomelanocortin and energy balance: insights from human and murine genetics. Journal of Clinical Endocrinology and Metabolism 89 2557-2562.

Cone RD 2005 Anatomy and regulation of the central melanocortin system. Nature Neuroscience 8 571-578.

Cowley MA, Smart JL, Rubinstein M, Cerdan MG, Diano S, Horvath TL, Cone RD \& Low MJ 2001 Leptin activates anorexigenic POMC neurons through a neural network in the acute nucleus. Nature $\mathbf{4 1 1} 480-484$.

Currie PJ, Coscina DV, Bishop C, Coiro CD, Koob GF, Rivier J \& Vale W 2001 Hypothalamic paraventricular nucleus injections of urocortin after food intake and respiratory quotient. Brain Research 916 222-228.

Eckel RH, Grundy SM \& Zimmet PZ 2005 The metabolic syndrome. Lancet 365 1415-1428.

Edwards CM, Abbott CR, Sunter D, Kim M, Dakin CL, Murphy KG, Abusnana S, Taheri S, Rossi M \& Bloom SR 2000 Cocaine- and amphetamine-regulated transcript, glucagon-like peptide-1 and corticotropin releasing factor inhibit feeding via agouti-related protein independent pathways in the rat. Brain Research 866 128-134.

Fan W, Boston BA, Kesterson RA, Hruby VJ \& Cone RD 1997 Role of melanocortinergic neurons in feeding and the agouti obesity syndrome. Nature 385 165-168.

Farooqi IS, Keogh JM, Yeo GS, Lank EJ, Cheetham T \& O’Rahilly S 2003 Clinical spectrum of obesity and mutations in the melanocortin 4 receptor gene. New England Journal of Medicine 348 1085-1095.

Ferreira I, Snijder MB, Twisk JW, van Mechelen W, Kemper HC, Seidell JC \& Stehouwer CD 2004 Central fat mass versus peripheral fat and lean mass: opposite (adverse versus favorable) association with arterial stiffness? The Amsterdam Growth and Health Longitudinal Study Journal of Clinical Endocrinology and Metabolism 89 2632-2639.

Flier JS 2004 Obesity wars: molecular progress confronts an expanding epidemic. Cell 116 337-350.

Friedman JM \& Halaas JL 1998 Leptin and the regulation of body weight in mammals. Nature $395763-770$.

Gropp E, Shanabrough M, Borok E, Xu AW, Janoschek R, Buch T, Plum L, Balthasar N, Hampel B, Waisman A et al. 2005 Agouti-related peptideexpressing neurons are mandatory for feeding. Nature Neuroscience $\mathbf{8}$ 1289-1291.

Gu D, Reynolds K, Wu X, Chen J, Duan X, Reynolds RF, Whelton PK, He J \& InterAsia Collaborative Group 2005 Prevalence of the metabolic syndrome and overweight among adults in China. Lancet 365 1398-1405.

Gutierrez-Juarez R, Obici S \& Rossetti L 2004 Melanocortin-independent effects of leptin on hepatic glucose fluxes. Journal of Biological Chemistry 279 49704-49715.

Halaas JL, Boozer C, Blair-West J, Fidahusein N, Denton DA \& Friedman JM 1997 Physiological response to long-term peripheral and central leptin infusion in lean and obese mice. PNAS 94 8878-8883.

Haskell-Luevano C \& Monck EK 2001 Agouti-related protein functions as an inverse agonist at a constitutive active brain melanocortin-4 receptor. Regulatory Peptides 99 1-7.

Haslam DW \& James WP 2005 Obesity. Lancet 366 1197-1209.

Haynes WG, Morgan DA, Djalali A, Sivitz WI \& Mark AL 1999 Interactions between the melanocortin system and leptin in control of sympathetic nerve traffic. Hypertension 33 542-547.

Heymsfield SB, Greenberg AS, Fujioka K, Dixon RM, Kushner R, Hunt T, Lubina JA, Patane J, Self B, Hunt P et al. 1999 Recombinant leptin for weight loss in obese and lean adults: a randomized, controlled, doseescalation trial. Journal of the American Medical Association 282 1568-1575.

Hoggard N, Ravner DV, Johnston SL \& Speakman JR 2004 Peripherally administered [Nle4,D-Phe7]- $\alpha$-melanocyte stimulating hormone increases resting metabolic rate, while peripheral agouti-related protein has no effect, in wild type C57BL/6 and $o b / o b$ mice. Journal of Molecular Endocrinology 33 693-703.

Hu FB, Willett WC, Li T, Stampfer MJ, Colditz GA \& Manson JE 2004 Adiposity as compared with physical activity in predicting mortality among women. New England Journal of Medicine 351 2694-2703.

Huszar D, Lynch CA, Fairchild-Huntress V, Dunmore JH, Fang Q, Berkemeier LR, Gu W, Kesteron RA, Boston BA, Cone RD et al. 1997 Targeted disruption of the melanocortin-4 receptor results in obesity in mice. Cell 88 131-141. 
Jacobson BC, Somers SC, Fuchs CS, Kelly CP \& Camargo CA Jr 2006 Bodymass index and symptoms of gastroesophageal reflux in woman. New England Journal of Medicine 354 2340-2348.

Jee SH, Sull JW, Park J, Lee SY, Ohrr H, Guallar E \& Samet JM 2006 Bodymass index and mortality in Korean men and women. New England Journal of Medicine 355 779-787.

Jegou S, Boutelet I \& Vaudry H 2000 Melanocortin-3 receptor mRNA expression in pro-opiomelanocortin neurons of the rat arcuate nucleus. Journal of Neuroendocrinology 12 501-505.

Kalra SP, Dube MG, Pu S, Xu B, Horvath TL \& Kalra PS 1999 Interacting appetite-regulating pathways in the hypothalamic regulation of body weight. Endocrine Reviews 20 68-100.

Kamohara S, Burcelin R, Halaas JL, Friedman JM \& Charron MJ 1997 Acute stimulation of glucose metabolism in mice by leptin treatment. Nature 389 374-377.

Kawamoto R, Tomita H, Oka Y, Kodama A \& Kamitani A 2005 Metabolic syndrome amplifies the LDL-cholesterol associated increases in carotid atherosclerosis. Internal Medicine 44 1232-1238.

Kenchaiah S, Evans JC, Levy D, Wilson PW, Benjamin EJ, Larson MG, Kannel WB \& Vasan RS 2002 Obesity and the risk of heart failure. New England Journal of Medicine 347 305-313.

Kim EM, Grace MK, Welch CC, Billington CJ \& Levine AS 1999 STZinduced diabetes decreases and insulin normalizes POMC mRNA in arcuate nucleus and pituitary in rats. American Journal of Physiology 276 R1320-R1326.

Kim EM, Grace MK, O'Hare E, Billington CJ \& Levine AS 2002 Injection of $\alpha$-MSH, but not $\beta$-endorphin, into the PVN decreases POMC gene expression in the Arc. Neuroreport 13 497-500.

Kim RY, Shin SW, Kim BJ, Lee W \& Baik JH 2005 Dynamic regulation of hypothalamic neuropeptide gene expression and food intake by melanocortin analogues and reversal with melanocortin-4 receptor antagonist. Biochemical and Biophysical Research Communications 329 1178-1185.

Kishi T, Aschkenasi CJ, Lee CE, Mountjoy KG, Saper CB \& Elmquist JK 2003 Expression of melanocortin 4 receptor mRNA in the central nervous system of the rat. Journal of Comparative Neurology 457 213-235.

Kitamura T, Feng Y, Kitamura YI, Chua SC Jr, Xu AW, Barsh GS, Rossetti L \& Accili D 2006 Forkhead protein FoxO1 mediates AgRP-dependent effects of leptin on food intake. Nature Medicine 12 534-540.

Kotz CM, Wang C, Levine AS \& Billington CJ 2002 Urocortin in the hypothalamic PVN increases leptin and affects uncoupling proteins-1 and -3 in rats. American Journal of Physiology. Regulatory, Integrative and Comparative Physiology 282 R546-R551.

Krude H, Biebermann H, Luck W, Horn R, Brabant G \& Gruters A 1998 Severe early-onset obesity, adrenal insufficiency and red hair pigmentation caused by POMC mutations in human. Nature Genetics 19 155-157.

Lam TKT, Pocai A, Gutierrez-Juarez R, Obici S, Bryan J, Aguilar-Bryan L, Schwartz GJ \& Rossetti L 2005 Hypothalamic sensing of circulating fatty acids is required for glucose homeostasis. Nature Medicine 11 320-327.

Li G, Mobbs CV \& Scarpace PJ 2003 Central pro-opiomelanocortin gene delivery results in hypophagia, reduced visceral adiposity, and improved insulin sensitivity in genetically obese Zucker rats. Diabetes 52 1951-1957.

Liu H, Kishi T, Roseberry AG, Cai X, Lee CE, Montez JM, Friedman JM \& Elmguist JK 2003 Transgenic mice expressing green fluorescent protein under the control of the melnaococrtin-4 receptor promoter. Journal of Neurochemistry 23 7143-7154.

Loftus TM, Jaworsky DE, Frehywot GL, Townsend CA, Ronnett GV, Lane MD \& Kuhajda FP 2000 Reduced food intake and body weight in mice treated with fatty acid synthesis inhibitors. Science 288 2379-2381.

Lu D, Willard D, Patel IR, Kadwell S, Overton L, Kost T, Luther M, Chen W, Woychik RP, Wilkison WO et al. 1994 Agouti protein is an antagonist of the melanocyte-stimulating hormone receptor. Nature 371 799-802.

Lu XY, Barsh GS, Akil H \& Watson SJ 2003 Interaction between $\alpha$-melanocyte-stimulating hormone and corticotropin-releasing hormone in the regulation of feeding and hypothalamo-pituitary-adrenal responses. Journal of Neuroscience 23 7863-7872.

Luo JD, Zhang GS \& Chen MS 2005 Leptin and cardiovascular diseases. Drug News and Perspectives 18 427-431.
Marceau P, Biron S, Hould FS, Marceau S, Simard S, Thung SN \& Kral JG 1999 Liver pathology and the metabolic syndrome X in severe obesity. Journal of Clinical Endocrinology and Metabolism 84 1513-1517.

Marks DL, Butler AA, Turner R, Brookhart G \& Cone RD 2003 Different role of melanocortin receptor subtypes in cachexia. Endocrinology 144 1513-1523.

Marks DL, Hruby V, Brookhart G \& Cone RD 2006 The regulation of food intake by selective stimulation of the type 3 melanocortin receptor (MC3R). Peptides 27 259-264.

Marsh DJ, Hollopeter G, Huszar D, Laufer R, Yagaloff KA, Fisher SL, Burn P \& Palmiter RD 1999 Response of melanocortin-4 receptor-deficient mice to anorectic and orexigenic peptides. Nature Genetics 21 119-122.

Martin NM, Small CJ, Sajedi A, Patterson M, Ghatei MA \& Bloom SR 2004 Pre-obese and obese agouti mice are sensitive to the anorectic effects of peptide YY3-35 but resistant to ghrelin. International Journal of Obesity 28 886-893.

Millington GW, Tung YC, Hewson AK, O'Rahilly S \& Dickson SL 2001 Differential effects of $\alpha$-, $\beta$-, and $\gamma 2$-melanocyte-stimulating hormones on hypothalamic neuronal activation and feeding in the fasted rat. Neuroscience 108 437-445.

Mizuno TM, Kleopoulos SP, Bergen HT, Roberts JL, Priest CA \& Mobbs CV 1998 Hypothalamic pro-opiomelanocortin mRNA is reduced by fasting and in $o b / o b$ and $d b / d b$ mice, but is stimulated by leptin. Diabetes $\mathbf{4 7}$ 294-297.

Mizuno TM, Kelley KA, Pasinetti GM, Roberts JL \& Mobbs CV 2003 Transgenic neural expression of proopiomelanocortin attenuates hyperphagic response to fasting and reverses metabolic impairments in leptindeficient obese mice. Diabetes 52 2675-2683.

Montanaro MS, Allen AM \& Oldfield BJ 2005 Structural and functional evidence supporting a role for leptin in central neural pathways influencing blood pressure in rats. Experimental Physiology 90 689-696.

Morrison CD, Morton DJ, Niswender KD, Gelling RW \& Schwartz MW 2005 Leptin inhibits hypothalamic NPY and $A g R P$ gene expression via a mechanism that requires phosphatidylinositol 3-OH-kinase signaling. American Journal of Physiology. Endocrinology and Metabolism 289 E1051-E1057.

Mountjoy KG, Mortrud MT, Low MJ, Simerly RB \& Cone RD 1994 Localization of the melanocortin-4 receptor (MC4-R) in neuroendocrine and autonomic control circuits in the brain. Molecular Endocrinology 8 $1298-1308$.

Munzberg H \& Myers MG Jr 2005 Molecular and anatomical determinants of central leptin resistance. Nature Neuroscience 8 566-570.

Munzberg H, Huo L, Nillni EA, Hollenberg AN \& Bjorbaek C 2003 Role of signal transducer and activator of transcription 3 in regulation of hypothalamic proopiomelanocortin gene expression by leptin. Endocrinology 144 2121-2131.

News feature 2004 Asia's big problem. Nature Medicine 10 325-327.

Nijenhuis WAJ, Oosterom J \& Adan RAH 2001 AgRP(83-132) acts as an inverse agonist on the human-melanocortin-4 receptor. Molecular Endocrinology 15 164-171.

Obici S, Zhang BB, Karkanias G \& Rossetti L 2002 Hypothalamic insulin signaling is required for inhibition of glucose production. Nature Medicine $\mathbf{8}$ 1376-1382.

Obici S, Feng Z, Arduini A, Conti R \& Rossetti L 2003 Inhibition of hypothalamic carnitine palmitoyltransfersae- 1 decreases food intake and glucose production. Nature Neuroscience 9 756-761.

Ogden CL, Carroll MD, Curtin LR, McDowell MA, Tabak CJ \& Flegal KM 2006 Prevalence of overweight and obesity in the United States 1999-2004. Journal of the American Medical Association 295 1549-1555.

Oh-I S, Shimizu H, Satoh J, Okada S, Adachi S, Inoue K, Eguchi H, Yamamoto M, Imaki T, Hashimoto K et al. 2006 Identification of nesfatin-1 as a satiety molecule in the hypothalamus. Nature 443 709-712.

Ollmann MM, Wilson BD, Yang YK, Kerns JA, Chen Y, Gantz I \& Barsh GS 1997 Antagonism of central melanocortin receptors in vitro and in vivo by agouti-related protein. Science 278 135-138.

Pierroz DD, Ziotopoulou M, Ungsunan L, Moschos S, Flier JS \& Mantzoros CS 2002 Effects of acute and chronic administration of the melanocortin agonist MT-II in mice with diet-induced obesity. Diabetes 51 1337-1345. 
Pocai A, Lam TK, Gutierrez-Juarez R, Obici S, Schwartz GJ, Bryan J, Aquilar-Bryan L \& Rossetti L 2005 Hypothalamic $\mathrm{K}_{\text {ATP }}$ channels control hepatic glucose production. Nature $\mathbf{4 3 4}$ 1026-1031.

Pritchard LE \& White A 2005 Agouti related protein: more than a melanocortin-4 receptor antagonist? Peptides 26 1759-1770.

Pritchard LE, Turnbull AV \& White A 2002 Pro-opiomelanocortin processing in the hypothalamus: impact on melanocortin signaling and obesity. Journal of Endocrinology 172 411-421.

Ren J 2004 Leptin and hyperleptinemia - from friend to foe for cardiovascular function. Journal of Endocrinology 181 1-10.

Roselli-Rehfuss L, Mountjoy KG, Robbins LS, Mortrud MT, Low MJ, Tatro JB, Entwistle ML, Simerly RB \& Cone RD 1993 Identification of a receptor for $\gamma$-melanocortin and other proopiomelanocortin peptides in the hypothalamus and limbic system. PNAS 90 8856-8860.

Saely CH, Aczel S, Marte T, Langer P, Hoefle G \& Drexel H 2005 The metabolic syndrome, insulin resistance, and cardiovascular risk in diabetic and nondiabetic patients. Journal of Clinical Endocrinology and Metabolism 90 5698-5703.

Schwartz MW \& Porte D Jr 2005 Diabetes, obesity, and the brain. Science 307 375-379.

Schwartz MW, Seeley RJ, Campfield LA, Burn P \& Baskin DG 1996 Identification of targets of leptin action in rat hypothalamus. Journal of Clinical Investigation 98 1101-1106.

Schwartz MW, Seeley RJ, Woods SC, Weigle DS, Campfield LA, Burn P \& Baskin DG 1997 Leptin increases hypothalamic pro-opiomelanocortin mRNA expression in the rostral arcuate nucleus. Diabetes 46 2119-2123.

Schwartz MW, Woods SC, Porte D Jr, Seeley RJ \& Baskin DG 2000 Central nervous system control of food intake. Nature 404 661-671.

Shimizu H \& Mori M 2005 The brain-adipose axis: a review of involvement of molecules. Nutritional Neuroscience 8 7-20.

Shimokawa T, Kumar MV \& Lane MD 2002 Effect of a fatty acid synthase inhibitor on food intake and expression of hypothalamic neuropeptides. PNAS 99 66-71.

Small CJ, Kim MS, Stanley SA, Mitchell JR, Murphy K, Morgan DJ, Ghatei MA \& Bloom SR 2001 Effects of chronic central nervous system administration of agouti-related protein in pair-fed animals. Diabetes $\mathbf{5 0}$ $248-254$

Spiegelman BM \& Flier JS 2001 Obesity and the regulation of energy balance. Cell 104 531-543.

Stanley S, Wynne K, McGowan B \& Bloom S 2005 Hormonal regulation of food intake. Physiological Reviews 85 1131-1158.

Ste Marie L, Miura GI, Marsh DJ, Yagaloff K \& Palmiter RD 2000 A metabolic defect promotes obesity in mice lacking melanocortin-4 receptors. PNAS 97 12339-12344.

Stein CJ \& Colditz GA 2004 The epidemic of obesity. Journal of Clinical Endocrinology and Metabolism 89 2522-2525.

Sundstrom J, Riserus U, Byberg L, Zethelius B, Lithell H \& Lind L 2006 Clinical value of the metabolic syndrome or long-term prediction of total and cardiovascular mortality: prospective, population based cohort study. British Medical Journal 332 878-882.

Sutton GM, Trevaskis JL, Hulver MW, McMillan RP, Markward NJ, Babin MJ, Meyer EA \& Butler AA 2006 Diet-genotype interactions in the development of the obese, insulin-resistant phenotype of C57BL/6J mice lacking melanocortin-3 or -4 receptors. Endocrinology 147 2183-2196.

Takahashi KA, Smart JL, Liu H \& Cone RD 2004 The anorexigenic fatty acid synthase inhibitor, C75, is a nonspecific neuronal activator. Endocrinology 145 184-193.

Tilg H \& Diehl AM 2000 Cytokines in alcoholic and non-alcoholic steatohepatitis. New England Journal of Medicine 343 1467-1476.
Uehara Y, Shimizu H, Ohtani K, Sato N \& Mori M 1998 Hypothalamic corticotropin-releasing hormone is a mediator of the anorexigenic effect of leptin. Diabetes 47 890-893.

van den Top M, Lee K, Whyment AD, Blanks AM \& Spanswick D 2004 Orexigen-sensitive NPY/AgRP pacemaker neurons in the hypothalamic arcuate nucleus. Nature Neuroscience 7 493-494.

Vergoni AV, Bertolini A, Wikberg JE \& Schioth HB 1999 Corticotropinreleasing factor (CRF) induced anorexia is not influenced by a melanocortin 4 receptor blockage. Peptides 20 509-513.

Vetter DE, Li C, Zhao L, Contarino A, Liberman MC, Smith GW, Marchuk Y, Koob GF, Heinemann SF, Vale W et al. 2002 Urocortin-deficient mice show hearing impairment and increased anxiety-like behavior. Nature Genetics 31 363-369.

Wajchenberg BL 2000 Subcutaneous and visceral adipose tissue: their relation to the metabolic syndrome. Endocrine Reviews 21 697-738.

Wardlaw SL, McCarthy KC \& Conwell IR 1998 Glucocorticoid regulation of hypothalamic proopiomelanocortin. Neuroendocrinology 67 51-57.

Weiss R, Dziura J, Burgert TS, Tamborlane WV, Taksali SE, Yeckel CW, Allen K, Lopes M, Savoye M, Morrison J et al. 2004 Obesity and the metabolic syndrome in children and adolescents. New England Journal of Medicine $\mathbf{3 5 0}$ 2362-2374.

Woods SC, Seeley RJ, Porte D Jr \& Schwartz MW 1998 Signal that regulates food intake and energy homeostasis. Science 280 1378-1383.

Xu B, Goulding EH, Zang K, Cepoi D, Cone RD, Jones KR, Tecott LH \& Reichardt LF 2003 Brain-derived neurotrophic factor regulates energy balance downstream of melanocortin-4 receptor. Nature Neuroscience $\mathbf{6}$ 736-742.

Yaswen L, Diehl N, Brennan MB \& Hochgeschwender U 1999 Obesity in the mouse model of pro-opiomelanocortin deficiency responds to peripheral melanocortin. Nature Medicine 5 1066-1070.

Yeo GSH, Farooqi IS, Challis BG, Jackson RS \& O'Rahilly S 2000 The role of melanocortin signaling in the control of body weight: evidence from human and murine genetic models. Quarterly Journal of Medicine 93 7-14.

Young JI, Otero V, Cerdan MG, Falzone TL, Chan EC, Low MJ \& Rubinstein M 1998 Authentic cell-specific and developmentally regulated expression of pro-opiomelanocortin genomic fragments in hypothalamic and hindbrain neurons of transgenic mice. Journal of Neuroscience $\mathbf{1 8}$ 6631-6640.

Yusuf S, Hawken S, Ounpuu S, Bautista L, Franzosi MG, Commerford P, Lang CC, Rumboldt Z, Onen CL, Lisheng L et al. 2005 Study Investigators Obesity and the risk of myocardial infarction in 27000 participants from 52 countries: a case-control study. Lancet 366 1640-1649.

Zhang Y, Kilroy GE, Henegan TM, Prpic-Uhing V, Richards WG, Bannon AW, Mynatt RL \& Gettys TW 2005 Targeted deletion of melanocortin receptor subtypes 3 and 4 , but not CART, alters nutrient portioning and compromises behavioral and metabolic responses to leptin. FASEB Journal 19 1482-1491.

Zheng H, Corkem MM, Crousillac SM, Patterson LM, Phifer CB \& Berthoud HR 2002 Neurochemical phenotype of hypothalamic neurons showing fos expression $23 \mathrm{~h}$ after intracranial AgPR. American Journal of Physiology. Regulatory, Integrative and Comparative Physiology 282 R1773-R1781.

Received in final form 7 December 2006 Accepted 11 December 2006 Made available online as an Accepted Preprint 27 December 2006 